\title{
Correction to: The Patient Experience of Fatigue in Systemic Lupus Erythematosus: A Conceptual Model
}

\author{
Sophie Cleanthous - Sara Strzok - Birgit Haier - Stefan Cano · \\ Thomas Morel
}

Published online: November 10, 2021

(C) The Author(s) 2021

Correction to: Rheumatol Ther

https://doi.org/10.1007/s40744-021-00374-0

In the original article published, the typesetters have missed the corrections provided by the author during proofing stage.

In the Methods and Acknowledgement sections, the abbreviated name 'Sophie Cleanthous' should be 'SCl' rather than 'SCi'.

The original article has been corrected.

The original article can be found online at https://doi. org/10.1007/s40744-021-00374-0.

S. Cleanthous $\cdot$ S. Strzok $\cdot$ S. Cano

Modus Outcomes, Letchworth Garden City, UK

B. Haier

UCB Pharma, Monheim, Germany

T. Morel $(\bowtie)$

UCB Pharma, Allée de la Recherche 60, 1070

Anderlecht, Brussels, Belgium

e-mail: Thomas.morel@ucb.com
Open Access. This article is licensed under a Creative Commons Attribution-NonCommercial 4.0 International License, which permits any non-commercial use, sharing, adaptation, distribution and reproduction in any medium or format, as long as you give appropriate credit to the original author(s) and the source, provide a link to the Creative Commons licence, and indicate if changes were made. The images or other third party material in this article are included in the article's Creative Commons licence, unless indicated otherwise in a credit line to the material. If material is not included in the article's Creative Commons licence and your intended use is not permitted by statutory regulation or exceeds the permitted use, you will need to obtain permission directly from the copyright holder. To view a copy of this licence, visit http://creativecommons.org/licenses/by$\mathrm{nc} / 4.0 /$. 